DOI: $10.5965 / 223811711632017308$

\title{
Avaliação do potencial agrícola e conflitos de uso das terras na microbacia Lajeado Pessegueiro, Santa Catarina
}

\author{
Evaluation of agricultural potential and conflicts of use of land in Lajeado Pessegueiro watershed, Santa \\ Catarina State, Brazil
}
Ludmila Nascimento Machado ${ }^{1}$, Arcângelo Loss ${ }^{*}$, Ivan Luiz Zilli Bacic ${ }^{2}$, Denilson Dortzbach ${ }^{2}$ e Heloísa de Campos Lalane ${ }^{2}$

Recebido em 01/12/2016 / Aceito em 15/05/2017

\section{RESUMO}

Este trabalho propôs o uso da Metodologia para Classificação da Aptidão de Uso das Terras do Estado de SC (MCAUTSC) e o Sistema de Avaliação da Aptidão Agrícola das Terras (SAAAT), para a avaliação da aptidão agrícola das terras e posterior identificação dos conflitos de uso na microbacia Lajeado Pessegueiro, Guarujá do Sul, SC. Para a elaboração do mapa de aptidão de uso das terras foi feita a sobreposição dos polígonos de fisiografia e do mapa de solos da microbacia. O mapa de Conflito de Uso das Terras resultou da sobreposição do Mapa de Aptidão Agrícola com os mapas de Uso e Cobertura das Terras. Por meio da metodologia de MCAUTSC, as classes de aptidão predominantes foram para lavouras (2d e 2e), com 35,92\% da área e pastagens (3dpr e 3 prp), com 45,21\% da área. Para os conflitos de uso, verificou-se o predomínio das classes subutilização $(31,20 \%)$, seguido das classes conflitos de uso $(28,45 \%)$ e uso com restrição $(23,43 \%)$, sendo a menor proporção para a classe uso sem restrição $(16,92 \%)$. Para o SAAAT, as classes de aptidão predominantes foram pastagens $(4 p=32,6 \%)$ e lavouras $(2=29,3 \%)$. Para os conflitos de uso, verificou-se predomínio da classe de uso sem restrição $(52,76 \%)$ e conflitos de uso $(23,61 \%)$, com menor proporção para a classe de uso com restrição $(6,25 \%)$. Na maior parte da área da microbacia, os dois métodos indicaram aptidão para pastagens, divergindo apenas em algumas áreas em que MCAUTSC indica pastagem e SAAAT indica aptidão regular para lavouras. No geral, as indicações para as áreas de lavouras também foram as mesmas nos dois métodos. O que difere os métodos entre si é que MCAUTSC define bem os fatores limitantes da área em questão, enquanto que o SAAAT demonstra mais os níveis de manejo baseado no nível tecnológico disponível.

PALAVRAS-CHAVE: sistema de informações geográficas, aptidão agrícola, planejamento racional do solo.

\begin{abstract}
The objective of this work proposed the use of the Methodology for Land Suitability Classification in Santa Catarina State (MCAUTSC) and the Evaluation System of Agricultural Land Suitability (SAAAT), to assess the agricultural land potential and subsequent identification of land use conflicts in the Lajeado Pessegueiro watershed, Guarujá do Sul, SC. For the preparation of the land use maps, polygon overlapping of the physiography and soil mapping were performed. The Land Use Conflict map resulted from the overlapping of the Land Evaluation map with the Land Use and Coverage map. Through MCAUTSC methodology, the predominant land evaluation classes were suitable to annual crops ( $2 \mathrm{~d}$ and $2 \mathrm{e}$ ), with $35.92 \%$ of the area and of pastures (3dpr and 3prp), with $45.21 \%$ of the area. For land use conflicts, there was a predominance of underutilization class $(31.20 \%)$, followed by land use conflicts class $(28.45 \%)$, use with restrictions $(23.43 \%)$ and use without restrictions class (16.92\%). For SAAAT, the predominant land evaluation classes were suitable to pasture $(4 \mathrm{p}=32.6 \%)$ and to annual crops $(2=29.3 \%)$. For land use conflicts, there was
\end{abstract}

${ }^{1}$ Universidade Federal de Santa Catarina, Florianópolis, SC, Brasil.

${ }^{2}$ Empresa de Pesquisa Agropecuária e Extensão Rural de Santa Catarina, Florianópolis, SC, Brasil.

*Autor para correspondência <arcangelo.loss@ufsc.br> 
a predominance of use without restriction (52.76\%) and use conflicts class $(23.61 \%)$, with the lowest proportion for land use without restriction $(6.25 \%)$. In most of the watershed area, both methods indicate suitability for pastures, differing only in some areas where MCAUTSC indicates pasture and SAAAT indicates regular suitability for annual crops. Overall, the indications for the annual crops areas were also the same considering both methods. The main difference between the methods is that MCAUTSC better defines the limiting factors of the area, while the SAAAT demonstrates the management level based on the level of available technology.

KEYWORDS: geographic information system, land evaluation, rational land use planning.

\section{INTRODUÇÃO}

O desconhecimento e, ou, a ausência de um planejamento racional do uso adequado das terras conforme o seu potencial, assim como a falta de informações sobre o recurso solo, tem favorecido a ocorrência de impactos negativos ao ambiente, tais como perdas de solo por erosão, acarretando em degradação ambiental e redução da qualidade de vida das pessoas (PEDRON et al. 2006, POELKING et al. 2015).

Desta forma, a caracterização dos efeitos dos sistemas de uso e manejo sobre a degradação e qualidade física do solo pode ser melhor quantificada por medidas que integram essas modificações (ARAUJO et al. 2004). Por exemplo, através da aptidão de uso é possível prever o desempenho das terras ao longo do tempo, de acordo com os tipos específicos de uso e manejo (VAN DIEPEN et al. 1991, ROSSITER 1996).

Existem diversas metodologias que foram criadas, com base na classificação interpretativa de levantamentos de solos visando a avaliação das terras. A Framework for Land Evaluation da FAO (FAO 1976) é uma das metodologias mais conhecidas no mundo, juntamente com a Land Capability Classification USDA/SCS (KLINGEBIEL \& MONTGOMERY 1961), a Land Use Capability Classification - Soil Survey of England and Wales - Grã-Bretanha (BIBBY \& MACKNEY 1969) e a Soil Capability Classification - Departament of Agriculture of Canadá (CANADA LAND INVENTORY 1965). Em relação ao Brasil, a nível nacional, existem dois sistemas que são mais utilizados: o Manual para Levantamento Utilitário e Classificação de Terras no Sistema de Capacidade de Uso (LEPSCH et al. 1991, 2015) e o Sistema de Avaliação da Aptidão Agrícola das Terras (RAMALHO FILHO \& BEEK 1995).

A definição dos graus limitantes relacionados com o uso das terras depende da interpretação dos valores e da importância que se dá a esses indicadores, que variam de acordo com o conhecimento e experiência de campo de cada avaliador. Dessa forma, variações de interpretação podem resultar na dificuldade da aplicação de métodos, pois causam incertezas, especialmente, quando são inseridas nos sistemas de informação geográficas (DELARMELINDA et al. 2011).

As metodologias existentes para se realizar a classificação da aptidão das terras podem ser utilizadas tanto para a avaliação quanto para o planejamento do uso adequado do solo para fins produtivos e de preservação dos recursos ambientais. SOARES et al. (2008), para determinar o potencial de uso agrícola na microbacia do rio Campestre, Colombo, PR, aplicaram e compararam os Sistema de Avaliação da Aptidão Agrícola das Terras (SAAAT), Capacidade de Uso da Terras (CUT) e Fragilidade Ambiental (FA) em conjunto com a legislação ambiental. Os autores concluíram que as metodologias utilizadas, SAAAT, CUT e FA, em conjunto com a legislação ambiental, representaram importantes instrumentos ao planejamento agrícola e ambiental, pois identificaram potencialidades e limitações, fornecendo subsídios para a elaboração de planos de uso e manejo, e tanto o SAAAT quanto o CUT obtiveram resultados de recomendações de uso do solo similares.

Por meio dos diferentes sistemas de aptidão das terras é possível fazer uma avaliação da performance das terras quando usadas para fins específicos. Como tal, fornece-se uma análise racional para a tomada de decisões de uso das terras com base nas relações entre o uso da terra, as estimativas dos insumos necessários e saídas projetadas (FAO 1984).

$\mathrm{Na}$ análise feita por DORTZBACH et al. (2013), os autores classificaram a aptidão das terras no município de Palmeira, SC, conforme a metodologia proposta por UBERTI et al. (1991), que foi desenvolvida especificamente para o Estado de Santa Catarina, e encontraram as classes 2 e 3 (classe 2 representa aptidão regular para culturas anuais e classe 3 representa aptidão com restrições para culturas anuais, aptidão regular para fruticultura 
e boa para pastagem e reflorestamento). As variações dessas classes de aptidão devem-se aos fatores limitantes dessa área, principalmente a declividade e susceptibilidade à erosão, porém os conflitos são ocasionados na maior parte por áreas subutilizadas e áreas com restrições, necessitando, dessa forma, de práticas de manejo do solo.

Para o desenvolvimento da agricultura há a necessidade do manejo do solo e da água, assim como saber utilizá-los de maneira racional. Partindo dessa premissa, é fundamental o conhecimento do potencial agrícola das terras para fazer o seu uso conforme a sua aptidão. E, no tocante de uma microbacia hidrográfica, o correto uso das terras é de suma importância para a preservação dos mananciais, assim como da manutenção da cobertura vegetal (LOSS et al. 2011).

Neste sentido, o presente trabalho propôs o uso da Metodologia para Classificação da Aptidão de Uso das Terras do Estado de SC (MCAUTSC) e o Sistema de Avaliação da Aptidão Agrícola das Terras (SAAAT), visando a avaliação da aptidão agrícola das terras e posterior identificação dos conflitos de uso na microbacia Lajeado Pessegueiro, Guarujá do Sul, SC.

\section{MATERIAL E MÉTODOS}

A microbacia Lajeado Pessegueiro abrange uma área de 980,51 hectares e localiza-se na região extremo Oeste Catarinense, no município de Guarujá do Sul, SC, Brasil (S 2623'4" e W 5331'15', altitude de 707 metros) e está entre os municípios limítrofes de Princesa e São José do Cedro. Os limites da microbacia (linha em amarelo) podem ser observados na Figura 1.

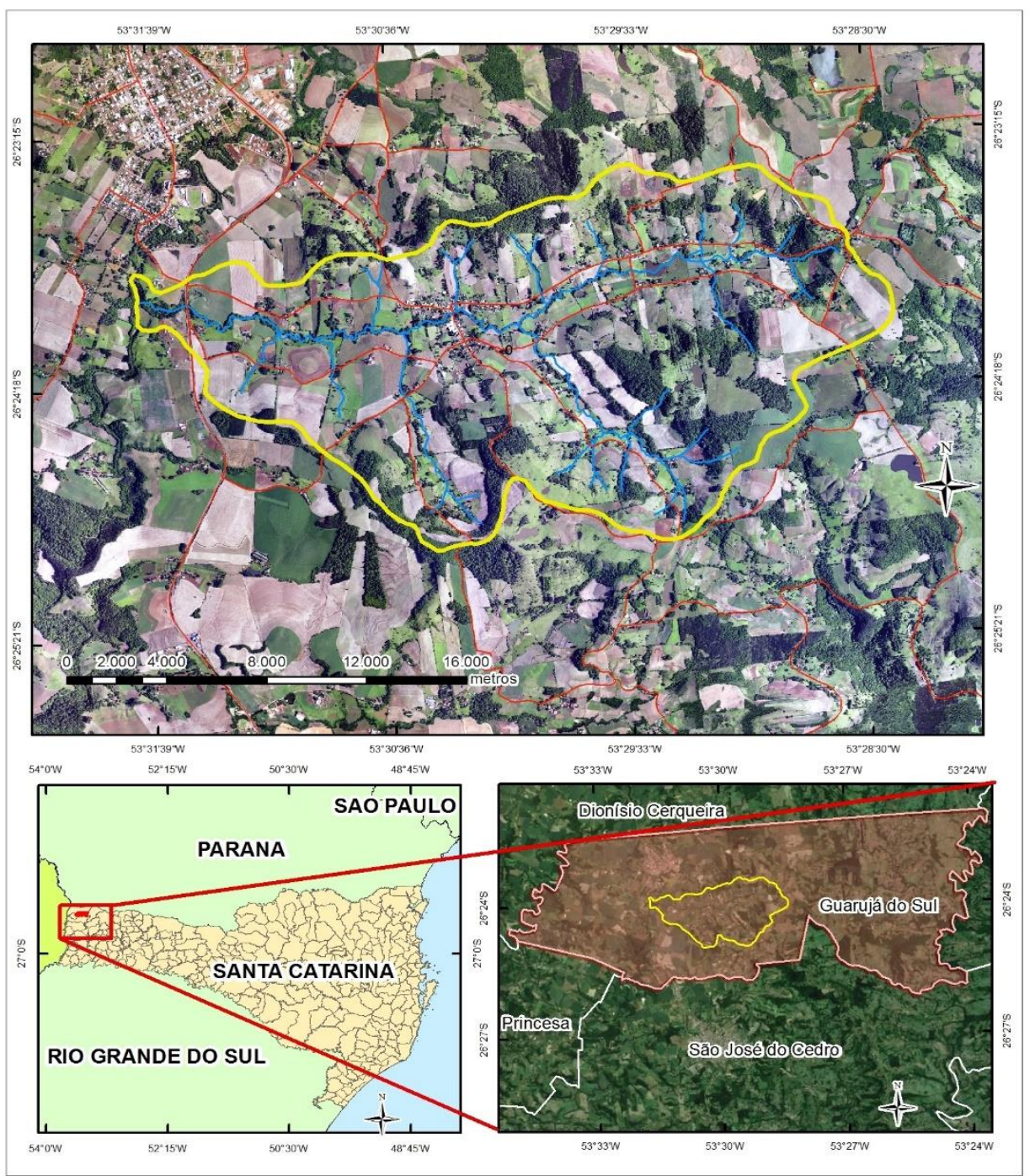

Figura 1. Mapa de localização da microbacia Lajeado Pessegueiro, Guarujá do Sul, SC.

Figure 1. Location map of the Lajeado Pessegueiro watershed, Guarujá do Sul, SC. 
No que se refere aos aspectos gerais, o município possui uma população de 4.908 habitantes, segundo IBGE (2010). A economia de Guarujá do Sul é baseada na exploração agropecurária, que emprega aproximadamente $50 \%$ da população economicamente ativa, a estrutura fundiária é caracterizada por minifúndio, onde $90 \%$ dos agricultores possuem área inferior a 50 hectares e utilizam mão de obra familiar. A microbacia Lajeado Pessegueiro abrange as comunidades Linha Pessegueiro, Linha Maidana, São Francisco, Bela Vista e Barro Preto, as quais contemplam cerca de 125 famílias, ou seja, 125 propriedades agrícolas caracterizadas principalmente pela exploração de gado leiteiro.

Segundo ROCHA (2014), Guarujá do Sul está inserido na formação Serra Geral, que é na verdade, a escarpa do planalto modelado nos derrames de rochas efusivas e nas camadas de rochas sedimentares da Bacia Sedimentar do Paraná. O tipo climático, de maneira geral, pode ser classificado como $\mathrm{Cfb}$, segundo Köppen, ou seja, clima temperado constantemente úmido, sem estação seca definida, com verão ameno (temperatura média do mês mais quente $<22,0{ }^{\circ} \mathrm{C}$ ), a precipitação total anual varia de 1.790 a $2.280 \mathrm{~mm}$, com a umidade relativa do ar entre 73 a 82\% (THOMÉ et al. 1999).

Em relação aos solos, o território catarinense apresenta grande diversidade de solos, os quais estão distribuídos acompanhando as variações de litologia e de relevo. Mais de $50 \%$ da área do estado é ocupada por solos desenvolvidos de rochas efusivas da Formação Serra Geral (basalto e riodacitos), correspondendo à metade do Oeste Catarinense (ROCHA 2014). Em Guarujá do Sul, a área é caracterizada por um relevo dissecado, constituído por patamares. A classe de solo predominante na região é a dos Cambissolos Háplicos, segundo EMBRAPA (2004) e UBERTI (2005).

Na região que abrange o município, a formação florestal predominante é da Floresta Ombrófila Mista (SANTACATARINA 1986), classificada como floresta de Araucária, com submata, na qual predominam as espécies florestais características como angico (Parapiptadenia rigida (Benth) Brenan), canela (Nectandra spp.) e araucária (Araucaria angustifolia (Bertol) Kuntze) (KLEIN 1978).

A elaboração dos mapas foi desenvolvida com o auxílio do software ArcGIS Dektop 10.0 e os materiais cartográficos utilizados foram: base cartográfica da Mapoteca topográfica digital IBGE/Epagri, em escala 1:50.000 (estradas, nascentes, limites) e ortofotos obtidas pelo Levantamento Aerofotogramétrico do Estado de Santa Catarina realizado em 2010/2011 (SDS/SC 2011).

Com o projeto "Levantamento e Mapeamento de Solos e Aptidão de Uso das terras Participativo e por Demanda" desenvolvido pela Epagri e com apoio do $\mathrm{CNPq}$, foi possível extrair os dados e parâmetros do levantamento e mapeamento de solos, e da análise fisiográfica realizada na microbacia Lajeado Pessegueiro, com as informações de coletas feitas em campo de 28 pontos de perfis de solo (MACHADO 2016), conforme a Figura 2.

Sendo assim, de acordo com a análise fisiográfica da Microbacia Lajeado Pessegueiro descrita por MACHADO (2016), por meio do projeto mencionado acima, foram observadas 5 subpaisagens: Encostas Erosionais, Erosionais Coluviais, Encostas em Patamar, Encostas Coluviais Erosionais e Fundos de Vale Coluviais Aluviais.

Os solos predominantes que foram classificados e mapeados segundo MACHADO (2016) na microbacia são: Nitossolos Vermelhos (37,5\%) e Cambissolos Háplicos $(35,2 \%)$, ocorrendo também Argissolos Vermelhos (10,0\%), Neossolos Litólicos $(5,0 \%)$ e Cambissolos Flúvicos (3,9\%) (Figura 2). O uso da terra foi identificado levando-se em consideração as classes normatizadas pelo Instituto Brasileiro de Geografia e Estatística (IBGE 2013), com reconhecimento a campo, ajuda dos agricultores e por meio de interpretação das imagens aéreas.

O mapa de Aptidão do Uso das terras foi elaborado a partir das metodologias nacional - SAAAT (RAMALHO FILHO \& BEEK 1995) e regional MCAUTSC (UBERTI et al. 1991). O SAAAT permite realizar uma avaliação de terras de natureza física, com base em atributos e tipos de utilização da terra, e produz informações referentes aos níveis de manejo (A, B e C), grupos (1, 2, 3, 4, 5 e 6), subgrupos (combinação dos níveis de manejo com os grupos) e classes de aptidão agrícola das terras (produto final).

Já a MCAUTSC faz uma adequação do SAAAT, contemplando a aptidão agrícola em pequenas áreas, assim incluindo o regime fundiário de Santa Catarina. Dessa forma, são definidas 5 classes de aptidão: classe 1- aptidão boa para culturas anuais, classe 2 aptidão regular para culturas anuais, classe 3 - aptidão com restrições para culturas anuais, classe 4 - aptidão com restrição para fruticultura e aptidão regular para pastagem e reflorestamento, e classe 5 - áreas de preservação permanente. Segundo essa metodologia, 


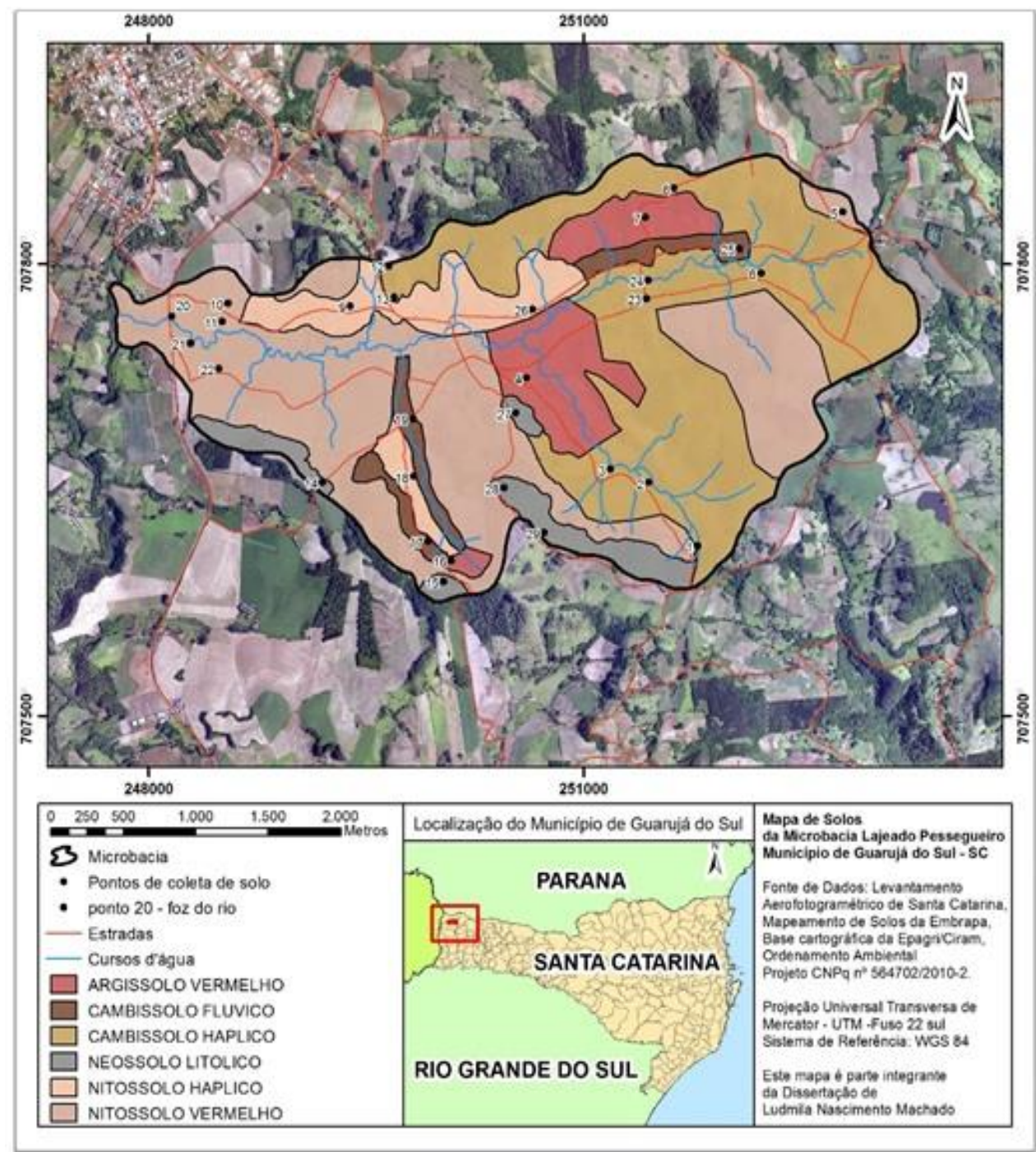

Figura 2. Mapa de solos contendo os 28 pontos de coleta na microbacia Lajeado Pessegueiro, Guarujá do Sul, $\mathrm{SC}$.

Figure 2. Soil map containing the 28 collection points in the Lajeado Pessegueiro watershed, Guarujá do Sul, $S C$.

as classes de aptidão devem ser definidas através dos seguintes parâmetros: declividade (d), profundidade efetiva do solo (pr), pedregosidade (p), suscetibilidade à erosão (e), fertilidade (f) e drenagem (d).

Os mapas de Aptidão de Uso das terras resultaram da extrapolação dos polígonos de fisiografia, reclassificados e corrigidos com os dados obtidos no Levantamento e Mapeamento de Solos da microbacia Lajeado Pessegueiro (MACHADO 2016). Para a vetorização da classe 5 de aptidão, inicialmente foi realizado o mapeamento das áreas de preservação permanente (APP), construído com base no novo Código Florestal Brasileiro (Lei ${ }^{\circ}$ 12.651/2012) e na Resolução n. 303 (CONAMA 2002). Foram classificadas áreas de matas ciliares de rios e nascentes, através de buffer de 30 metros a partir da vetorização da drenagem e das nascentes, conforme as legislações citadas.

O Conflito de Uso das Terras resultou da sobreposição do Mapa de Aptidão Agrícola com as informações relacionadas ao Uso e Cobertura das Terras. As classes de conflito de uso das terras utilizadas, conforme PANICHI et al. (1994) foram: (a) Subutilização - leva em consideração a intensidade de uso. São terras que poderiam ser utilizadas mais intensivamente, sem prejuízos à conservação das mesmas, salvaguardando a questão econômica e ambiental; (b) Uso sem restrições enquadram-se nesta classe as terras que estão sendo utilizadas conforme a sua vocação natural; (c) Uso 
com restrições - são terras que estão sendo utilizadas de acordo com a sua aptidão de uso, mas apresentam riscos de deterioração, necessitando intensas medidas de manejo e conservação do solo e (d) Conflitos de Uso - comtempla terras que estão sendo utilizadas com atividades agropecuárias fora da sua vocação natural e, se mantidas, comprometem a conservação da água e do solo.

Com a utilização do SIG, ArcGis Dektop 10.0, as áreas de cada classe de uso, aptidão agrícola e conflito de uso foram calculadas, sendo possível fazer a quantificação de cada área em relação à área total da microbacia. As áreas das feições dos diferentes mapas são calculadas da mesma forma, através da ferramenta Calculate Geometry, que está disponível ao abrir a janela de atributos do layer. Após o cálculo das áreas, a tabela é exportada para o Excel, onde são calculadas as porcentagens referentes a cada classe.

\section{RESULTADOS E DISCUSSÃO}

\section{Áreas de Preservação Permanente (APPs)}

O mapa elaborado conforme o Código Florestal Brasileiro (Lei $n^{\circ}$ 12.651/2012) e na Resolução n. 303 (CONAMA 2002), mostra a representação espacial das APPs (Figura 3). As áreas de APP's foram identificadas e classificadas por áreas de matas ciliares de rios e nascentes, através de buffer de 30 metros a partir da vetorização da drenagem e das nascentes, conforme as legislações citadas. Do total da área da microbacia, 137,90 hectares (14\%) são de APPs, sendo a maior parte encontrada próximos das nascentes e matas ciliares.

\section{Uso e ocupação do solo na microbacia}

O uso das terras é predominantemente ocupado com culturas temporárias, com destaque para o milho e

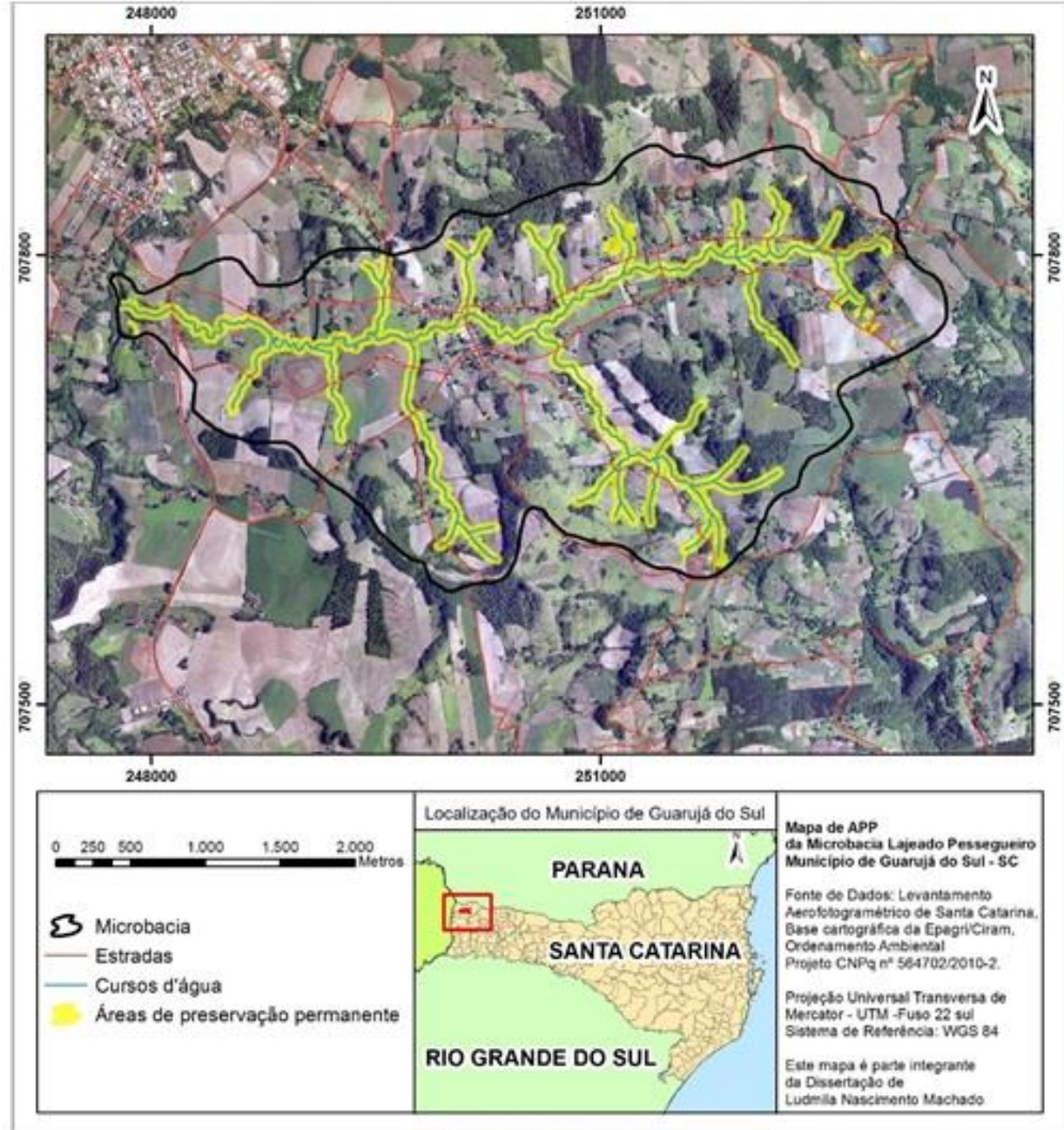

Figura 3. Áreas de preservação permanente da microbacia Lajeado Pessegueiro, Guarujá do Sul, SC. Figure 3. Permanent preservation areas of the Lajeado Pessegueiro watershed, Guarujá do Sul, SC. 
a soja, totalizando 491,15 hectares, o que corresponde $50,09 \%$ da área total que é de 980,5 hectares. Também evidenciou-se o uso com floresta $(20,89 \%)$, principalmente em áreas como topos de morro e com maiores declividades, assim como presença de poucas áreas desmatadas $(1,81 \%)$ e com solo exposto $(0,41 \%)$. As áreas com pastagem plantada, principalmente azevém, ocupam 19,69\% da área total, voltadas para a criação de gado leiteiro, atividade agrícola observada na maior parte das propriedades da microbacia, sendo também a principal atividade local. As áreas de reflorestamento ocupam 2,51\%, sendo estas com cultivo de eucalipto e pinus. A massa d'agua correspondente aos rios, açudes e nascentes é representada com 1,11\%. A área urbanizada aparece com 3,49\% da área total (Figura 4).

\section{Aptidão de uso das terras pela metodologia de SC (MCAUTSC)}

Com a aplicação do método proposto por UBERTI et al. (1991), foi possível encontrar quatro classes de aptidão de uso das terras, assim como as suas respectivas áreas ocupadas (Figura 5). $\mathrm{Na}$ microbacia Lajeado Pessegueiro observa-se uma aptidão de uso das terras com 45,21\% enquadrada na classe 3, que são terras com restrições para culturas anuais climaticamente adaptadas, porém com aptidão regular para fruticultura e boa aptidão para pastagens e reflorestamento. Desse total, $24,35 \%$ da área apresentou classificação $3 \mathrm{dpr}$, ou seja, classe 3 com limitações por declividade e profundidade e, 20,86\% com a classificação 3prp, com limitações por profundidade e pedregosidade. Segundo UBERTI et al. (1991), são terras que apresentam alto risco de degradação ou limitações fortes para utilização com culturas anuais climaticamente adaptadas, necessitando de intensas práticas conservacionistas do solo, como por exemplo o sistema de plantio direto, uso de terraços, etc. Porém, podem ser usados com segurança com pastagens, fruticultura ou reflorestamento com práticas simples de manejo e conservação do solo, através de pastoreio controlado, cultivo em faixa, cobertura morta, adubação verde, entre outras.

A classe 3dpr foi encontrada nas encostas erosionais, nas quais existe uma predominância de Cambissolos Háplicos, e também ocorrência de Argissolos Vermelhos e Neossolos Litóticos. A classe 3 prp foi encontrada nas encostas em patamares, sendo nestas encontrados os Neossolos Litólicos e
Nitossolos Vermelhos.

A classe 2 com aptidão regular para culturas anuais climaticamente adaptadas (representada em cores marrons na Figura 4) ocorre em 35,92\% da área. Dentro dessa classe observaram-se limitações por declividade (2d) ocupando $31,32 \%$ da área e limitações por suscetibilidade à erosão (2e) com $4,60 \%$ da área total. Apesar das limitações presentes nessa classe, as culturas implantadas podem ser utilizadas desde que sejam aplicadas práticas de manejo adequadas de conservação e manejo do solo (UBERTI et al. 1991). Práticas como o sistema plantio direto, faixas de retenção permanente, cultivo em faixa, manutenção da cobertura do solo, são exemplos que podem auxiliar no controle da erosão do solo, principalmente ocasionada pela declividade. A classe $2 \mathrm{~d}$ foi encontrada nas encostas erosionais coluviais e os solos dominantes nesta feição, na sua maior parte, são os Cambissolos Háplicos, Nitossolos Háplicos, Argissolos Vermelhos e Neossolos Litólicos.

As áreas com classes 1 e 5, apresentaram, respectivamente, $5,91 \%$ e $12,96 \%$ da área total da microbacia (Figura 4). As áreas com classe 1, que apresentam aptidão boa para culturas anuais climaticamente adaptadas, são terras com nenhuma ou muito pequenas limitações e, ou, riscos de degradação, geralmente situadas em relevo plano ou suave ondulado. Esta classe foi encontrada nas áreas de fundo de vales, representadas por Cambissolos Flúvicos. Já a classe 5 é representada por áreas de preservação permanente, terras impróprias para qualquer tipo de cultivo, normalmente situam-se em áreas próximas ao rio e topos de morro (UBERTI et al. 1991).

\section{Conflitos de uso conforme a MCAUTSC}

A sobreposição das informações de uso e cobertura do solo com as classes de aptidão (Figuras 4 e 5), gerou o mapa de conflitos de uso das terras (Figura 6). Verificaram-se quatro classes, sendo que a classe de subutilização ocorre praticamente em toda a área da microbacia e representa $31,20 \%$ da área total. Essa classe considera fatores conservacionistas do solo e não leva em consideração os fatores econômicos e sociais da área estudada.

Foi observado nas áreas consideradas subutilizadas, o uso com pastagens, onde a aptidão recomenda a utilização com culturas agrícolas, isto é, essas áreas que se encontram subutilizadas, possuem um potencial de aptidão para um uso da terra mais 


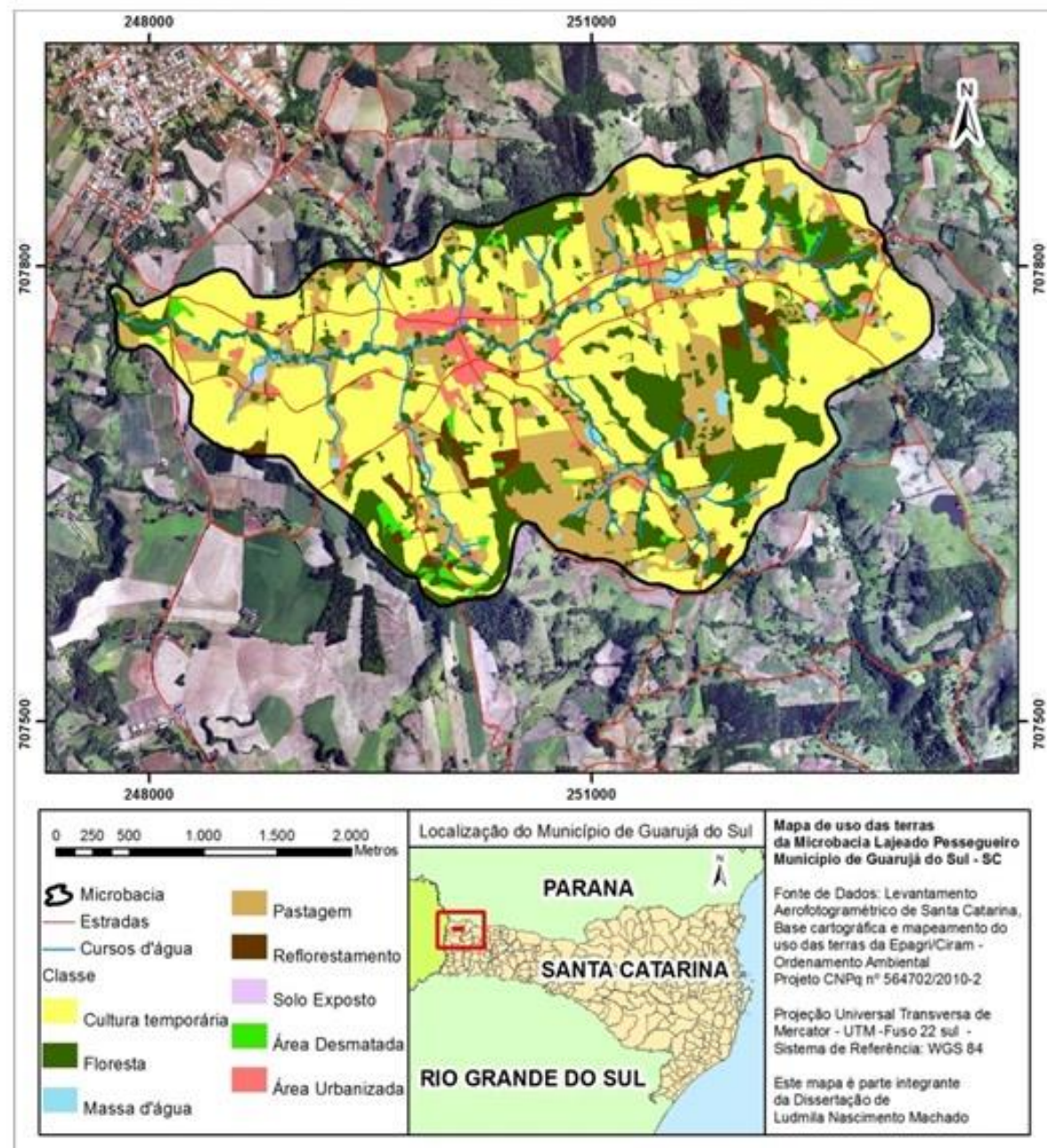

Figura 4. Mapa de uso e ocupação das terras da microbacia Lajeado Pessegueiro, Guarujá do Sul, SC. Figure 4. Map of land use and occupation of Lajeado Pessegueiro watershed, Guarujá do Sul, SC.

intensivo do que o uso observado atualmente.

No trabalho de SILVA et al. (2010), os autores observaram que, na área de estudo do Assentamento Eldorado dos Carajás, em Lebon Régis, SC, as terras subutilizadas somaram $21,5 \%$ da área total do assentamento. A classe de aptidão agrícola indicou o uso com cultivos agrícolas, mas atualmente elas vêm sendo utilizadas com pastagens ou com a exploração de espécies florestais. Ainda segundo os autores, nas áreas em que a classe de aptidão recomenda o uso com pastagens, os agricultores praticam a silvicultura.

A classe de conflito de uso foi observada nas áreas de maior altitude da microbacia, representando $28,45 \%$. Nessas áreas, a aptidão de uso restringe o uso com culturas agrícolas anuais, porém essas áreas são ocupadas com esse tipo de uso, sendo necessárias intensas e complexas medidas de manejo e conservação do solo, por se tratar de áreas com alto risco de degradação. No estudo feito por HADLICH
(2006), a autora identificou que 4,8\% (310 ha) da área total estudada no município de Sombrio, SC, se enquadra na classe de uso com alta restrição, pois apresenta o cultivo de frutíferas (banana) em área de risco para o desenvolvimento de processos erosivos acelerados.

Para PEDRON et al. (2006), que encontraram $27,9 \%$ da sua área de estudo no município de São João do Polêsine, RS, em conflito de uso, a principal causa é a presença de lavoura e pastagens em áreas com aptidão para silvicultura e preservação permanente. Isso se deve à fragilidade desses ambientes relacionados às maiores declividades, juntando fatores como pedregosidade e rochosidade, que provocam restrições ao uso de mecanização, assim como a ocorrência de solos com menor profundidade efetiva, sendo mais suscetíveis a erosão, estresse hídrico e oferecendo maiores restrições ao desenvolvimento radicular das culturas anuais, como é o exemplo 
dos Neossolos Litólicos e Cambissolos Háplicos, encontrados na microbacia em estudo, nas áreas com maiores declividades e que estão enquadradas nessa classe de conflito de uso.

A classe de uso com restrição ocupa $23,43 \%$ da microbacia. De acordo com a aptidão de uso, são terras que apresentam limitações moderadas para a utilização com culturas agrícolas, com riscos moderados de degradação. A causa dessa divergência na maior parte dessas áreas, deve-se a presença de culturas agrícolas em áreas com declividades acentuadas. Essas áreas estão sendo utilizadas de acordo com sua aptidão, porém, esse tipo de cultura pode ser usado, desde que aplicadas práticas de manejo adequadas de conservação e manejo do solo que evitem perdas por erosão principalmente nas áreas com classe de aptidão $2 \mathrm{~d}$.

A classe de Uso sem restrição ocorre em 16,92\% da área total. Nessas áreas, o uso atual corresponde ao uso indicado pela classe de aptidão, ou seja, essas áreas estão sendo utilizadas com a sua capacidade máxima sem causar degradação aos recursos naturais. Utilizando a metodologia do SAAAT, PEDRON et al. (2006), observaram que em 51,5\% do município de São João do Polêsine, RS, o uso está de acordo com a indicação da aptidão. Assim como SILVA et al. (2010), que observaram que $44,3 \%$ das terras do Asssentamento Eldorado dos Carajás em Lebon Régis, SC, estão com uso satisfatório, ou seja, o uso atual atende à classe de aptidão agrícola definida.

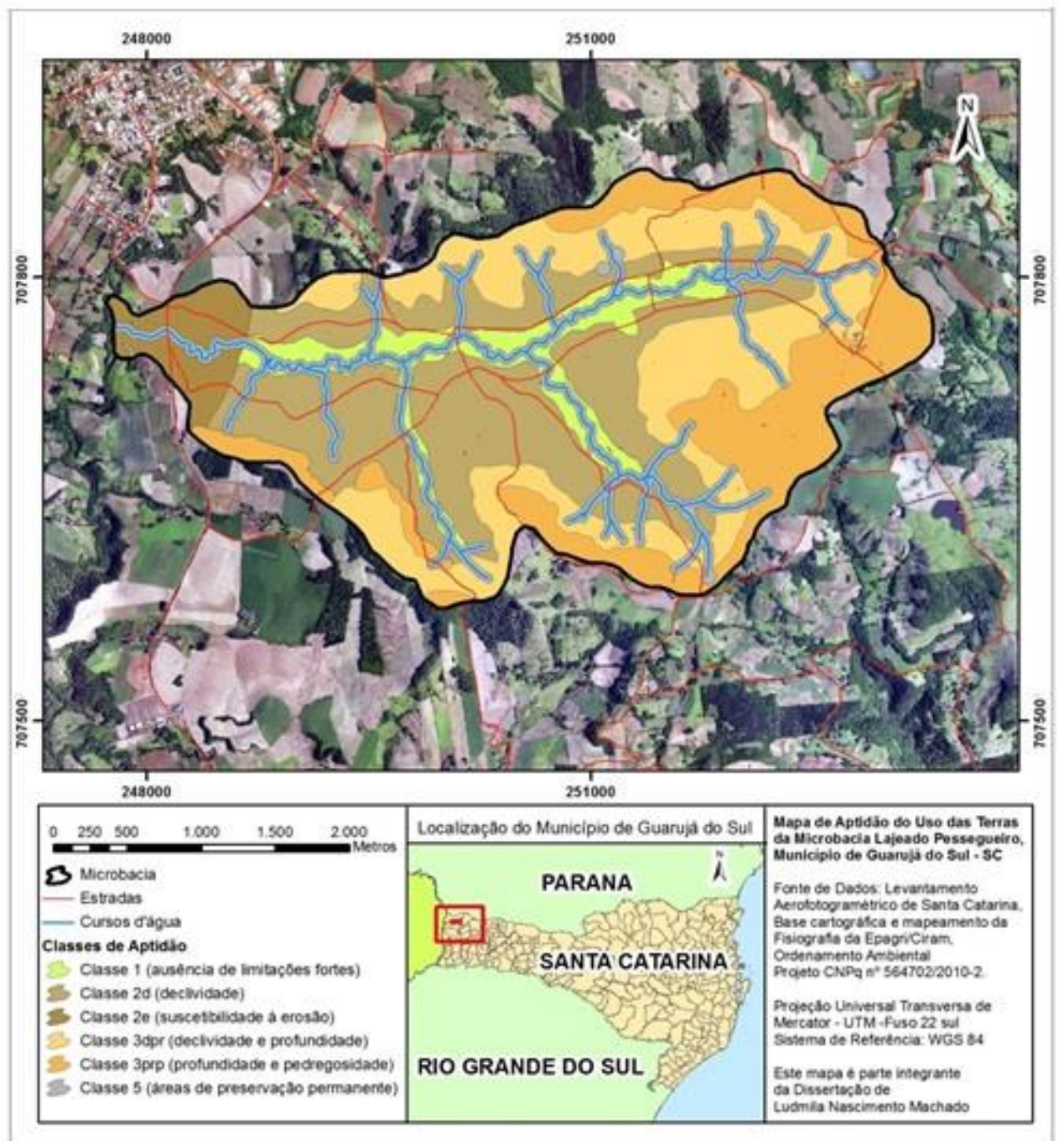

Figura 5. Mapa de aptidão de uso das terras na microbacia Lajeado Pessegueiro, Guarujá do Sul, SC, conforme metodologia de UBERTI et al. (1991).

Figure 5. Land use suitability map in Lajeado Pessegueiro watershed, Guarujá do Sul, SC, according to UBERTI et al. (1991). 


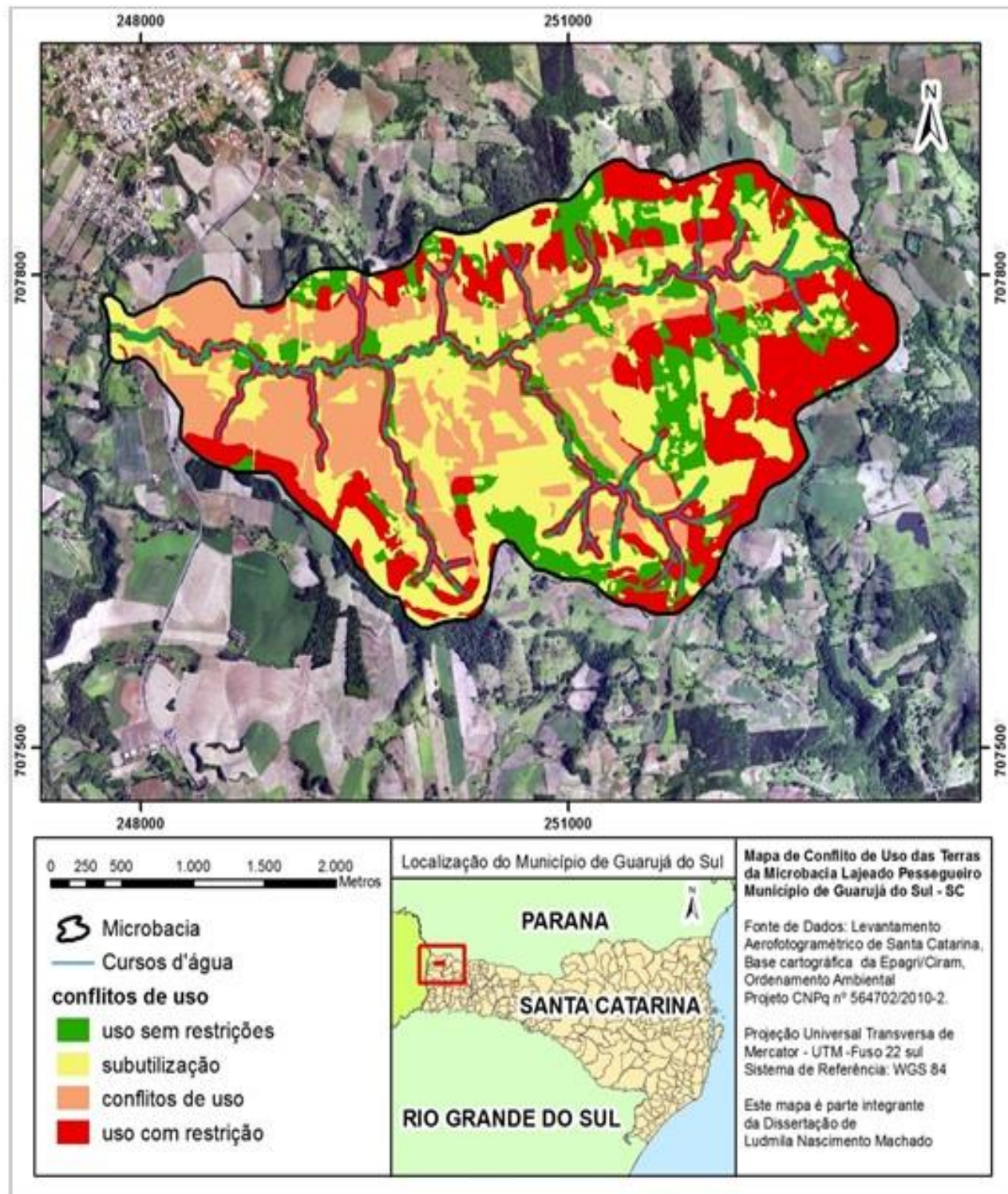

Figura 6. Mapa de conflitos de uso das terras na microbacia Lajeado Pessegueiro, Guarujá do Sul, SC, conforme metodologia de UBERTI et al. (1991).

Figure 6. Land use conflicts map in Lajeado Pessegueiro watershed, Guarujá do Sul, SC, according to UBERTI et al. (1991).

\section{Avaliação da aptidão agrícola das terras conforme o SAAAT}

O resultado da avaliação da aptidão agrícola das terras mostrou que foram encontrados cinco grupos de aptidão na área estudada $(1,2,3,4$ e 6$)$ e onze subgrupos, sendo que $54,4 \%$ das terras da microbacia possuem aptidão para lavouras (Figura 7).

A classe mais representativa foi a $4 \mathrm{p}$, ocupando 319,30 hectares, ou seja, $32,6 \%$ da área total da microbacia, e de acordo com o método aplicado, indica terras com aptidão regular para pastagem plantada. Dos solos que ocorrem nessa classe estão o
Cambissolo Háplico e o Nitossolo Vermelho, em áreas de maiores altitudes e com relevo forte ondulado, o que faz com que aumente a suscetibilidade à erosão e os impedimentos à mecanização. SILVA (2007), avaliando a aptidão agrícola das terras por meio SAAAT, no assentamento Eldorado dos Carajás, SC, também encontrou a classe $4 p$ como predominante. A autora explica que o relevo movimentado da área avaliada, associado à baixa fertilidade natural do solo, pedregosidade e afloramentos rochosos, constituem as principais limitações quanto ao uso agrícola destes solos. 


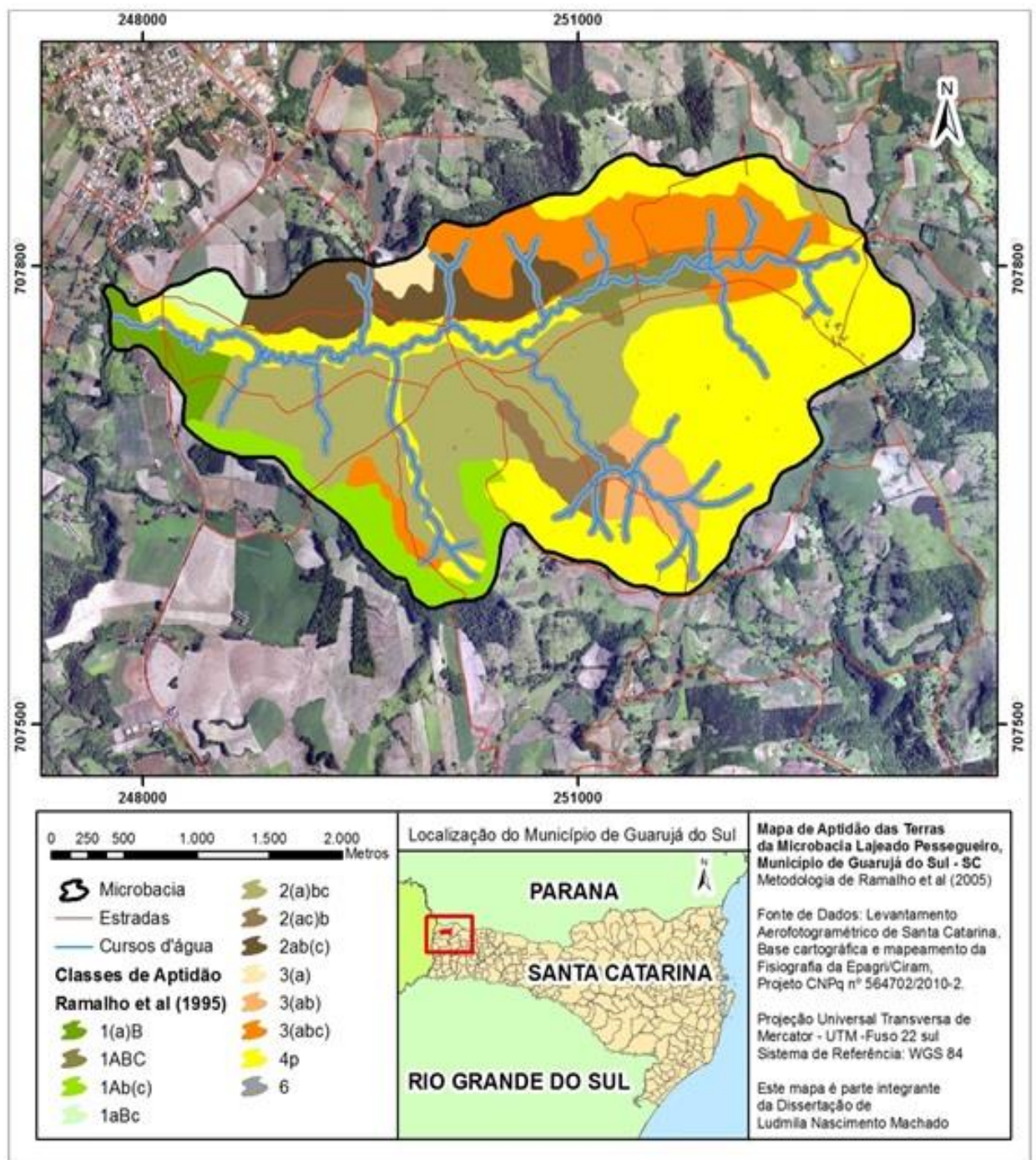

Figura 7. Mapa de aptidão agrícola das terras na microbacia Lajeado Pessegueiro, Guarujá do Sul, Santa Catarina, conforme metodologia de RAMALHO FILHO \& BEEK (1995).

Figure 7. Agricultural land suitability map in Lajeado Pessegueiro watershed, Guarujá do Sul, Santa Catarina, according to the methodology of RAMALHO FILHO \& BEEK (1995).

Os grupos de aptidão 1,2 e 3 englobam as terras com aptidão boa, regular e restrita, respectivamente, para lavouras de ciclo curto e, ou, longo nos três níveis de manejo (A, B, C). Para as classes de uso das terras do grupo 1 verificou-se que elas ocupam uma área de 109,89 hectares (11,2\%). Dentre as classes, os subgrupos encontrados foram $1(\mathrm{a}) \mathrm{B}, 1 \mathrm{Ab}(\mathrm{c}), 1 \mathrm{aBc}$ e $1 \mathrm{ABC}$.

$\mathrm{Na}$ classe 1(a)B foi possível observar a ocorrência de Nitossolo Vermelho em área de menor declividade em que predominam o transporte e acúmulo de sedimentos, os fatores limitantes se devem à questões de fertilidade e impedimentos à mecanização. O subgrupo $1 \mathrm{Ab}(\mathrm{c})$ é representado por Neossolo Litólico e este por ser um solo raso, com pedregosidade, impede a mecanização, fator limitante principal para esse subgrupo, nesse caso se torna inviável o seu melhoramento. A classe $1 \mathrm{aBc}$ situa-se na área de ocorrência de Nitossolo Vermelho, que são solos com textura argilosa ou muito argilosa, o que causa impedimentos à mecanização quando muito secos ou molhados. Outro fator limitante dessa classe é a fertilidade, que se devem aos valores baixos de fósforo e potássio, que pode ser solucionado através de melhoramento viável com práticas simples, como por exemplo a adubação de NPK. O subgrupo $1 \mathrm{ABC}$ não possui nenhum fator limitante, sendo para esse grupo verificado os solos caracterizados por Cambissolos Háplicos Eutróficos.

No trabalho realizado por CORSEUIL et 
al. (2009), no qual os autores avaliaram a aptidão agrícola das terras pelo SAAAT, na microbacia do Arroio Ajuricaba, no município de Marechal Cândido Rondon, PR, os mesmos concluíram que mais de $70 \%$ da área estudada possui aptidão para lavouras, embora apresentem diferentes graus de limitações que requerem tratamentos distintos para a sua conservação. Os autores verificaram que as melhores terras para a exploração agrícola nos três níveis de manejo (1ABC) ocupam apenas 56 hectares ou 3,3\% do total da área e se encontram em áreas com a ocorrência de Latossolos Vermelhos Eutroférricos.

As classes do grupo de aptidão agrícola 2 ocupam 287,10 hectares $(29,3 \%$ da área total). Os subgrupos de aptidão encontrados foram 2(a)bc, $2(a c) b$ e $2 a b(c)$. Na classe 2(a)bc, observou-se a ocorrência na maior parte por Nitossolos Háplicos e algumas áreas com Argissolos Vermelhos e uma pequena parte com Cambissolos Háplicos. Esses solos possuem características similares em relação a baixa fertilidade natural e geralmente apresentam altos teores de acidez, o que necessita de investimentos relacionados com adubação e calagem. Outro fator limitante para essa classe de aptidão, além da fertilidade, se refere a impedimentos à mecanização e erosão. Os Cambissolos, pela localização no relevo, aliado a presença de rochas e pedregosidade, restringe o processo de mecanização.

As terras do grupo de aptidão 3 foram enquadradas nas classes 3(a), 3(ab) e 3(abc), e ocupam uma área de 136,78 hectares (14\%). O principal fator limitante para essa classe de aptidão é a mecanização e erosão, e a ocorrência de Cambissolos Háplicos, tornam essas áreas restritas em função desses graus de limitação.

O grupo 6 refere-se a terras inaptas para qualquer um dos tipos de utilização já mencionados, a não ser em casos especiais. Na microbacia uma área de 127,42 hectares é ocupada por essa classe. As terras consideradas inaptas classificadas da classe 6 são voltadas para a preservação da flora e da fauna, nas quais deve ser estabelecida ou mantida uma cobertura vegetal. $\mathrm{Na}$ área de estudo encontram-se predominantemente próximos aos cursos d'água, conforme a Figura 2.

\section{Conflitos de uso das terras conforme o SAAAT}

Por meio do cruzamento do Mapa de Aptidão Agrícola (Figura 7) com o Mapa de Uso das Terras (Figura 4) resultou o mapa de Conflito de Uso das Terras (Figura 8). Verifica-se que uma parte representativa $(52,76 \%)$ da área da microbacia está com Uso sem restrições, ou seja, o uso atual está de acordo com o que é recomendado pela classe de aptidão agrícola estabelecida pelo método utilizado, como por exemplo, as áreas com classe de aptidão $1 \mathrm{Ab}(\mathrm{c}), 1(\mathrm{a}) \mathrm{B}$ e $4 \mathrm{p}$. Essas áreas referem-se às áreas ocupadas com tipo de uso adequado, tais como lavouras (grupo 1) e pastagens (grupo 4), somando um total de 517,32 hectares. A classe 6 está sendo ocupada com florestas (mata ciliar) no entorno dos rios.

Para a classe de Uso com restrição, uma área de 61,24 ha $(6,25 \%)$ foi identificada. Essas áreas se encontram ocupadas por lavouras e a aptidão indica que podem ser exploradas com pastagem (4p) e lavouras nas classes 2(a)bc e $2 \mathrm{ab}(\mathrm{c})$, por exemplo. Nessas áreas, a atividade agrícola observada está conforme a aptidão recomenda, porém, para que se faça esse tipo de cultivo, são necessárias intensas medidas de manejo e conservação de solo, pois apresentam riscos de deterioração.

As terras consideradas subutilizadas ocupam uma área de 170,43 hectares (17,38\%). Geralmente são áreas em que a aptidão indica o uso de lavouras e as mesmas estão ocupadas por pastagem. Isso significa que essas terras não estão sendo exploradas no seu máximo potencial, ou seja, poderiam ser utilizadas mais intensivamente sem causar prejuízo à conservação do solo e da água. Porém, essa classificação não leva em consideração fatores sociais e econômicos da região e sim leva em consideração apenas a intensidade do uso. Os agricultores, mesmo diante desse tipo de informação, continuam optando por manter as pastagens, pois é a atividade mais explorada na região, além de uma questão cultural.

Os conflitos de uso da microbacia ocupam 231,51 hectares $(23,61 \%)$. É possível observar em toda a extensão ao longo do rio, áreas que deveriam ser destinadas para preservação permanente, e estão sendo usadas com lavouras ou pastagens, deixando evidente a principal causa do conflito de uso. Vale salientar que essas áreas de conflito de uso contemplam terras que seriam destinadas para questões ambientais legais e também que estão sendo utilizadas com atividades fora da sua vocação natural e acima da capacidade máxima de uso das terras, e que se mantidas, comprometem a conservação da água e do solo, pois estão acima da capacidade do potencial de exploração dessas terras. 


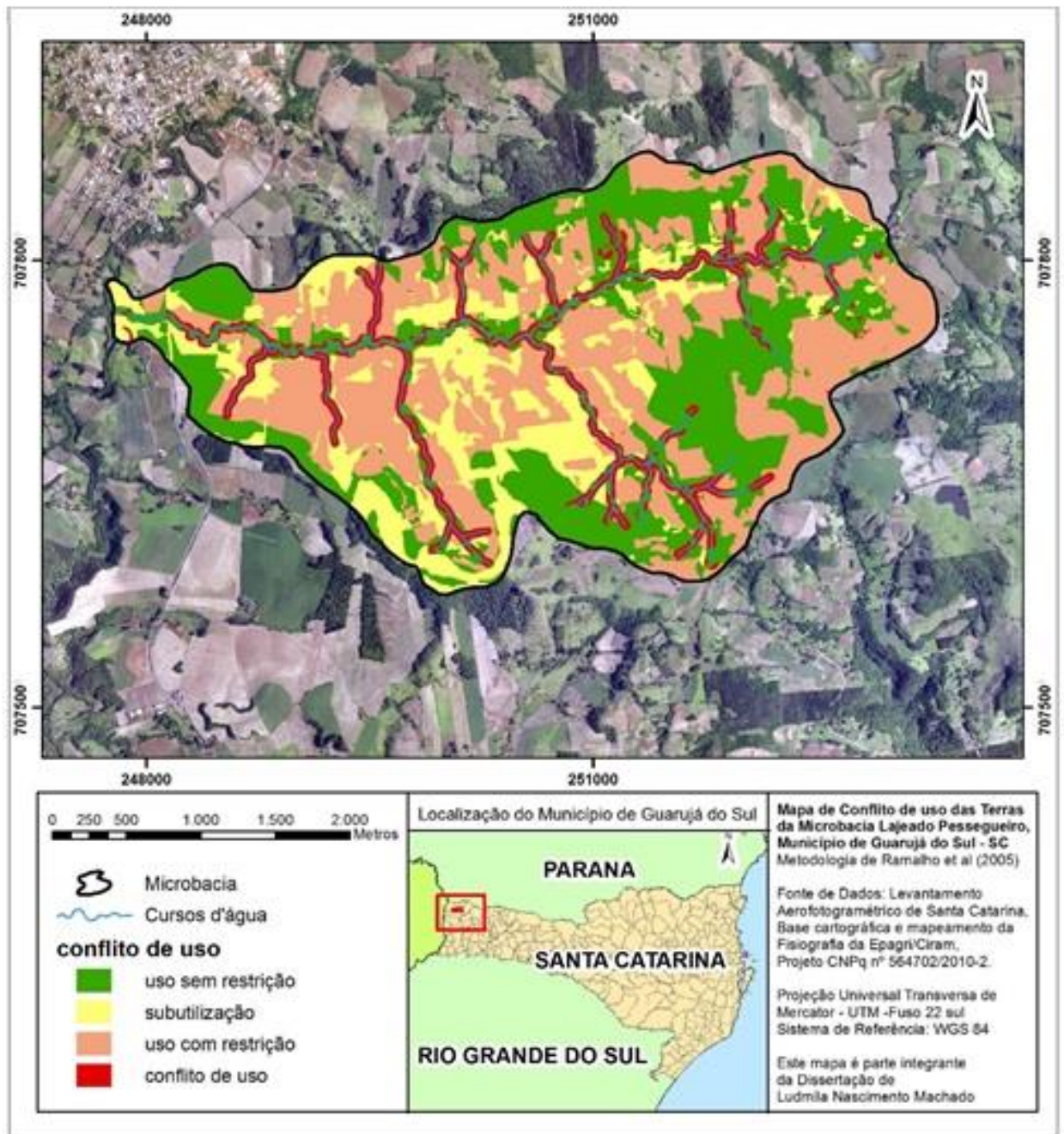

Figura 8. Mapa de conflitos de uso das terras na microbacia Lajeado Pessegueiro, Guarujá do Sul, Santa Catarina, conforme a metodologia de RAMALHO FILHO \& BEEK (1995).

Figure 8. Land use conflicts map in Lajeado Pessegueiro watershed, Guarujá do Sul, Santa Catarina, according to the methodology of RAMALHO FILHO \& BEEK (1995).

\section{Considerações sobre as metodologias utilizadas}

Quando comparado os mapas indicadores de conflitos de uso elaborado a partir de cada método, a classe de subutilização na MCAUTSC aparece com $31,20 \%$ do total da área, enquanto que o SAAAT possui $17,38 \%$ das terras inseridas nessa classe. Para UBERTI et al. (1991), isso se deve principalmente pelas áreas onde são verificados usos com floresta e utilização com pastagem e que poderiam ser exploradas com culturas agrícolas. Quando verificado por RAMALHO FILHO \& BEEK (1995), o fator que condiciona a classe de subutilização é o uso de pastagens em áreas que tem aptidão para lavouras, que poderiam ser mais intensamente exploradas.

Pode-se também observar as áreas de conflitos de uso, nas quais a MCAUTSC indica que $28,45 \%$ da área está com conflitos de uso e pelo SAAAT, 23,61\% está com esse uso. Para UBERTI et al. (1991), nessas áreas o recomendado seria pastagem, sendo o uso atual observado com lavouras, assim explicando o porque do conflito na metodologia estadual. Em uma parte das áreas conflitantes com base no RAMALHO FILHO \& BEEK (1995), as áreas de preservação de mata ciliar estão sendo ocupadas por pastagens e lavouras. Essas áreas mencionadas estão localizadas em áreas de encostas erosionais e encostas em patamar, onde pode ser observado a ocorrência de Cambissolos Háplicos e Neossolos Litólicos.

Em uma grande parte das encostas erosionais, os dois métodos propuseram um potencial uso para pastagens, sendo essa atividade a ideal para o tipo de relevo encontrado nessas encostas. Por meio das 
metodologias utilizadas e somados ao uso de técnicas de geoprocessamento e sensoriamento remoto, foi possível obter maior eficiência na verificação da adequação do uso das terras, assim como relatado por outros trabalhos (SILVA et al. 1999, ALVARENGA et al. 2003, LOSS et al. 2011). De acordo com LOSS et al. (2011), o uso de geotecnologias pode servir como ferramenta importante para a recomendação de uso em nível de microbacia hidrográfica através do levantamento semi-detalhado dos solos.

Contudo, observando a atual Metodologia para Classificação da Aptidão de Uso das terras do Estado de Santa Catarina, nota-se a necessidade de uma proposta de atualização dessa metodologia, devido às diversas transformações ocorridas no cenário estadual após os mais de 20 anos da publicação. Nesse período ocorreram mudanças na legislação ambiental (BRASIL 2012), criação do zoneamento agrícola de risco climático e critérios que definem a possibilidade de aquisição de financiamento agrícola (BRASIL 2008), mudança no perfil dos produtores, êxodo rural, produção de novas culturas, abandono de outras, avanços expressivos de mecanização, aperfeiçoamento de técnicas de manejo do solo.

SILVA et al. (2010) utilizaram o SAAAT visando o desenvolvimento agrícola de terras reformadas e a identificação de possíveis conflitos decorrentes do uso da terra no Projeto de Assentamento Eldorado dos Carajás, em SC. Os autores verificaram que, a partir do cruzamento das informações temáticas geradas (dados cadastrais, solos, declividade, aptidão agrícola no nível de manejo B, uso atual e restrições legais) via SIG, foi possível identificar os conflitos de uso das terras por parcela imobiliária e propor alternativas para sua adequação de uso.

CORSEUIL et al. (2009) avaliaram a aptidão da microbacia do Arroio Ajuricaba, localizada no município de Marechal Cândido Rondon, PR, a partir da interpretação do levantamento pedológico da área, em nível de semi-detalhe, e com base na metodologia do SAAAT. Com o intuito de planejar o uso dos recursos naturais dessa microbacia, esses autores verificaram que a classe de aptidão mais representativa foi a 1 (a)Bc, e concluíram que as terras vêm sendo utilizadas de forma adequada de acordo com as recomendações de aptidão de uso e para a preservação dos recursos naturais da bacia hidrográfica.

De maneira geral, quando os fatores limitantes da área estudada, verifica-se que há uma necessidade de implantação de práticas de manejo e conservação, por meio de assistência técnica, para que além da conservação dos recursos naturais (água e solo), possa resultar no aumento da sustentabilidade econômica das propriedades agrícolas.

\section{CONCLUSÃO}

Na maior parte da área da microbacia, os dois métodos indicaram aptidão para pastagens, divergindo apenas em algumas áreas em que a MCAUTSC indica pastagem e o SAAAT indica aptidão regular para lavouras. No geral, as indicações para as áreas de lavouras também foram as mesmas nos dois métodos.

$\mathrm{O}$ que difere os métodos entre si é que na MCAUTSC se definem bem os fatores limitantes da área em questão, enquanto que o SAAAT demonstra mais os níveis de manejo baseado no nível tecnológico disponível.

A maior diferença entre as metodologias foi observada ao definir as áreas de conflito de uso, onde evidenciou-se que a MCAUTSC foi mais restritiva quanto a essa classe, ou seja, indicou mais áreas com restrição e conflitos de uso do que o SAAAT. No geral, a maior causa dessa divergência, foi a existência de áreas utilizadas com lavouras em áreas em que a aptidão indica pastagem.

\section{REFERÊNCIAS}

ALVARENGA BS et al. 2003. O ensino de conceitos e práticas de espectroradiometria laboratorial: estudo de caso com solos do Estado de São Paulo. In: XI Simpósio Brasileiro de Sensoriamento Remoto, Belo Horizonte. Anais.... São José dos Campos: INPE. p. 739-747.

ARAUJO MA et al. 2004. Propriedades físicas de um Latossolo Vermelho distrófico cultivado e sob mata nativa. Revista Brasileira de Ciência do Solo 28: 337-345.

BIBBY JS \& MACKNEY D. 1969. Land use capability classification. The Soil Survey Technical Monograph n.1. Technical Monography (Soil Survey of England and Wales), n.1. Harpenden: Rothamsted Experimental Station. $27 \mathrm{p}$.

BRASIL. 2008. Ministério da Agricultura Pecuária e Abastecimento. Secretaria de Política Agrícola. Instrução Normativa $\mathrm{N}^{\circ}$ 2, de 9 de outubro de 2008, Disponível em: $<$ http://www.in.gov.br/visualiza/index.jsp?data $=10 / 10 / 200$ 8 ejornal $=1$ epagina $=71$ etota 1 Arquivos $=152>$. Acesso em: 10 nov. 2015.

BRASIL. 2012. Ministério da Agricultura Pecuária e Abastecimento. Código Florestal. Lei $\mathrm{n}^{\circ} 12.651$ de 25 de maio de 2012. Disponível em: <http://www.planalto. 
gov.br/ccivil_03/_Ato2011-2014/2012/Lei/L12651.htm>. Acesso em: 10 nov. 2015.

CANADA LAND INVENTORY. 1956. The Canada land inventory: soil capability classification for agriculture, Ottawa. 16p.

CONAMA - Conselho Nacional do Meio Ambiente. 2002. Resolução $N^{\circ} 303$ de 20 de março de 2002. Dispõe sobre parâmetros, definições e limites de Áreas de Preservação Permanente. Disponível em: <http://www.mma.gov.br/ port/conama/res/res02/res30302.html . Acesso em: 13 mar. 2015.

CORSEUIL CW et al. 2009. Geoprocessamento e Sensoriamento Remoto aplicado na determinação da aptidão agrícola de uma microbacia. Irriga 14: 12-22.

DELARMELINDA EA et al. 2011. Avaliação da Aptidão Agrícola de solos do Acre por diferentes especialistas. Revista Brasileira de Ciência do Solo 35: 1841-1853.

DORTZBACH D et al. 2013. Conflito de uso do solo da microbacia Mato Escuro, município de Palmeira, SC. In: XVI Simpósio Brasileiro de Sensoriamento Remoto. Anais..... Foz do Iguaçu: SBSR. p. 207-214.

EMBRAPA. 2004. Empresa Brasileira de Pesquisa Agropecuária. Centro Nacional de Pesquisa de Solos. Solos do Estado de Santa Catarina. Rio de Janeiro: Embrapa Solos. 745p.

FAO. 1984. Guidelines: land evaluation for rainfed agriculture. Rome: FAO. 5p. (FAO Soils Bulletin 52).

FAO. 1976. A framework for land evaluation. Rome: FAO 72p. (FAO Soils Bulletin 32). Disponível em: <http://www. fao.org >. Acesso em: 08 out. 2014.

HADLICH GM. 2006. Análise de relações entre declividade e uso do solo com auxílio do geoprocessamento, município de Sombrio, SC. In: VI Simpósio Nacional de Geomorfologia/Regional Conference on Geomorfhology. Resumos..... Goiânia: UFG. p. 1-6

IBGE - Instituto Brasileiro de Geografia e Estatística. 2013. Manual técnico de uso da terra. 3. ed. Rio de Janeiro: IBGE. 171p.

IBGE - Instituto Brasileiro de Geografia e Estatística. 2010. Estimativa da população de 2010. Disponível em: $<$ http://www.ibge.gov.br/home/estatistica/populacao/ censo2010/>. Acesso em: 26 abr. 2017.

KLEIN RM. 1978. Flora Ilustrada Catarinense: Mapa Fitogeográfico do Estado de Santa Catarina. Itajaí: Herbário Barbosa Rodrigues, V Parte - mapa fitogeográfico. 24p.

KLINGEBIEL AA \& MONTGOMERY PH. 1961. Land capability classification. Washington: Soil Conservation Service. 21p. (Handbook, 210).

LEPSCH IF et al. 2015. Manual para Levantamento utilitário e classificação de terras no sistema de capacidade de uso. Viçosa: SBCS. 170p.

LEPSCH IF et al. 1991. Manual para levantamento utilitário do meio físico e classificação de terras no sistema de capacidade de uso. $4^{\mathrm{a}}$ aproximação, $2^{\mathrm{a}}$ impressão rev. Campinas: Viçosa: SBCS. 175p.
LOSS A et al. 2011. Aplicação de Modelo Digital de Elevação Para o Levantamento de Solos da Microbacia do Rio Bengala, em Cachoeiras de Macacu, Rio de Janeiro, Brasil. Interciencia 36: 121-127.

MACHADO LN. 2016. Caracterização das classes de solos, aptidão agrícola das terras e análise da vulnerabilidade do solo na microbacia Lajeado Pessegueiro, Guarujá do Sul, SC. Dissertação (Mestrado em Agroecossistemas). Florianópolis: UFSC. 135p.

PANICHI JAV et al. 1994. Metodologia para o inventário das terras em microbacias hidrográficas. Florianópolis: EPAGRI. 50p.

PEDRON FA et al. 2006. Aptidão de uso da terra como base para planejamento da utilização dos recursos naturais no município de São João Polênise - RS. Ciência Rural 36: 105-112.

POELKING EL et al. 2015. Sistema de informação geográfica aplicado ao levantamento de solos e aptidão agrícola das terras como subsídios para o planejamento ambiental do município de Itaara, RS. Revista Árvore 39: 215-223.

RAMALHO FILHO A \& BEEK KJ. 1995. Sistema de avaliação da aptidão agrícola das terras. 3.ed. Rio de Janeiro: CNPS/Embrapa. 65p.

ROCHA IO. 2014. Secretaria de Estado do Planejamento. Atlas de Santa Catarina: Diversidade da Natureza. Fascículo 2. Florianópolis: Editora UDESC. 188p.

ROSSITER DG. 1996. A theoretical framework for land evaluation. Geoderma 72: 165-202.

SANTA CATARINA. 1986. Gabinete de Planejamento e Coordenação Geral. Subchefia de Estatística, Geografia e Informática. Atlas de Santa Catarina. Rio de Janeiro: Aerofoto Cruzeiro. 173p.

SDS/SC. 2011. Secretaria do Desenvolvimento Econômico Sustentável. Programa de Levantamento Aerofotogramético do Estado de Santa Catarina. Disponível em: $<$ http://www. sigsc.sds.sc.gov.br/>. Acesso em: 06 nov. 2015.

SILVA EB. 2007. Avaliação da aptidão agrícola das terras como subsídio à reforma agrária: assentamento Eldorado dos Carajás - SC. Dissertação (Mestrado em Engenharia Civil). Florianópolis: UFSC. 147p.

SILVA AB et al. 1999. Caracterização do meio físico da microbacia Quatro Bocas, em Angelim, PE, e sua quantificação por sistema de informação geográfica. Pesquisa Agropecuária Brasileira. 34:109-117.

SILVA EB et al. 2010. Avaliação da aptidão agrícola das terras como subsídio ao assentamento de famílias rurais, utilizando sistemas de informações geográficas. Revista Brasileira de Ciência do Solo 34: 1977-1990.

SOARES MRGJ et al. 2008. Potencial de uso agrícola e fragilidade ambiental da microbacia do Rio Campestre, Colombo - PR. Scientia Agraria 9: 587-596.

THOMÉ VMR et al. 1999. Zoneamento agroecológico e socioeconômico do Estado de Santa Catarina. Florianópolis: Epagri. (CD-Rom). 
UBERTI AAA. 2005. Santa Catarina: Proposta de Divisão Territorial em Regiões Edafoambientais Homogêneas. Tese (Doutorado em Engenharia Civil). Florianópolis: UFSC. $201 p$.

UBERTI AAA et al. 1991. Metodologia para classificação da aptidão de uso das terras do Estado de Santa Catarina. Florianópolis: Empasc; Acaresc. 19p. (Empasc. Documentos, 119).

VAN DIEPEN CA et al. 1991. Land evaluatio: from intituition to quantification. In: STEWART BA. (ed.). Advances in Soil Science. New York: Springer. p.139-204. 